\title{
Green purchase intention: The power of success in green marketing promotion
}

\author{
Fauziyah Nur Jamal ${ }^{a^{*}}$, Norfaridatul Akmaliah Othman ${ }^{a}$, Raden Chairul Saleh ${ }^{b}$ and Safira \\ Chairunnisa $^{b}$
}

${ }^{a}$ Universiti Teknikal Malaysia Melaka, Malaysia

${ }^{b}$ Universitas Islam Indonesia

\section{H R O N I C L E}

Article history:

Received: September 18, 2020

Received in revised format:

November 182020

Accepted: December 12, 2020

Available online:

December 15, 2020

Keywords:

Green Marketing Promotion

Property Industry

Green Purchase Intention

Structural Equation Modelling

(SEM)

System Dynamics

\section{A B S T R A C T}

The development of green marketing has received the attention of various levels of business around the world. The promotion of green marketing is now shaping all business sectors' practices, including the property industry. Yogyakarta is one of the cities whose industry has been developing so fast. This study explored green purchase intention to succeed in green marketing promotion. It examined how the relationship between green purchase intention with the variables supporting it and measuring its value. This research was completed with two methods: identifying the relationship between the green purchase intention variables (endogenous) with variables and their indicators (exogenous) that affect the value of green purchase intention. The identification using structural equation modelling. While the measurement of green purchase intention values was carried out using a dynamic system simulation. The data was collected through the survey method on 400 sample sizes. The results obtained, a significant relationship between 4 exogenous variables and the endogenous variable and also obtained some prediction value per unit time.

\section{Introduction}

Growing concerns about environmental sustainability and climate change bring all companies to the challenge of integrating environmental issues into business strategies and activities (Dangelico \& Vocalelli, 2017). In order to respond to these environmental demands, companies should develop new strategies that can guarantee fulfilment with these green issues, such as green marketing. Every company competes to apply the green marketing concept in its business strategy that leads to activities that care about the environment. According to Polonsky (1994), the aim of green marketing is to meet human needs and desires, so that satisfaction with these needs and desires occurs without harming the natural environment. Consumer is one of the most important sides to consider in support green revolution. By better understanding their characteristics and consumption behaviour, companies could influence them to buy green product. To succeed in good promotion relating green product, determinants of consumers green purchase behaviour are need to be explored. Before the formation of the green purchase behaviour, there must be an intention to buy green products that commonly referred as green purchase intentions. According to Rashid (2009), green purchase intention is conceptualized as a person's probability and willingness to give preference to products that have environmentally friendly features compared to other traditional products in consideration of their purchases. By identifying this customer green purchase intention, it will bring to customer satisfaction. The development of green building has received attention of various levels of business around the world. The promotion of green marketing is now shaping the practice of all business sectors including real estate development. Real Estate Indonesia (REI) is an association that houses several brand developers in real estate in Indonesia. Established on February 11, 1972, REI has a goal to fill Indonesia's

* Corresponding author.

E-mail address: fauziyahnj@gmail.com (F. N. Jamal) 
development, especially in the housing sector as a mirror of the welfare of the Indonesian people. Many developers are registered as members of REI and for the Yogyakarta region there are around 294 registered brands. REI has provided a campaign for developers to apply the green concept, and many brand developers have applied the green concept to their property business. In this study, researchers wanted to examine consumers' green purchase intentions and examine the relationship between these green purchase intentions variables and to know the value of green purchase intention in Real Estate Indonesia (REI) Yogyakarta.

\section{Literature review}

There are several literatures to develop the ck-chart, the literatures are about green marketing in brand trust which is green purchase intention.

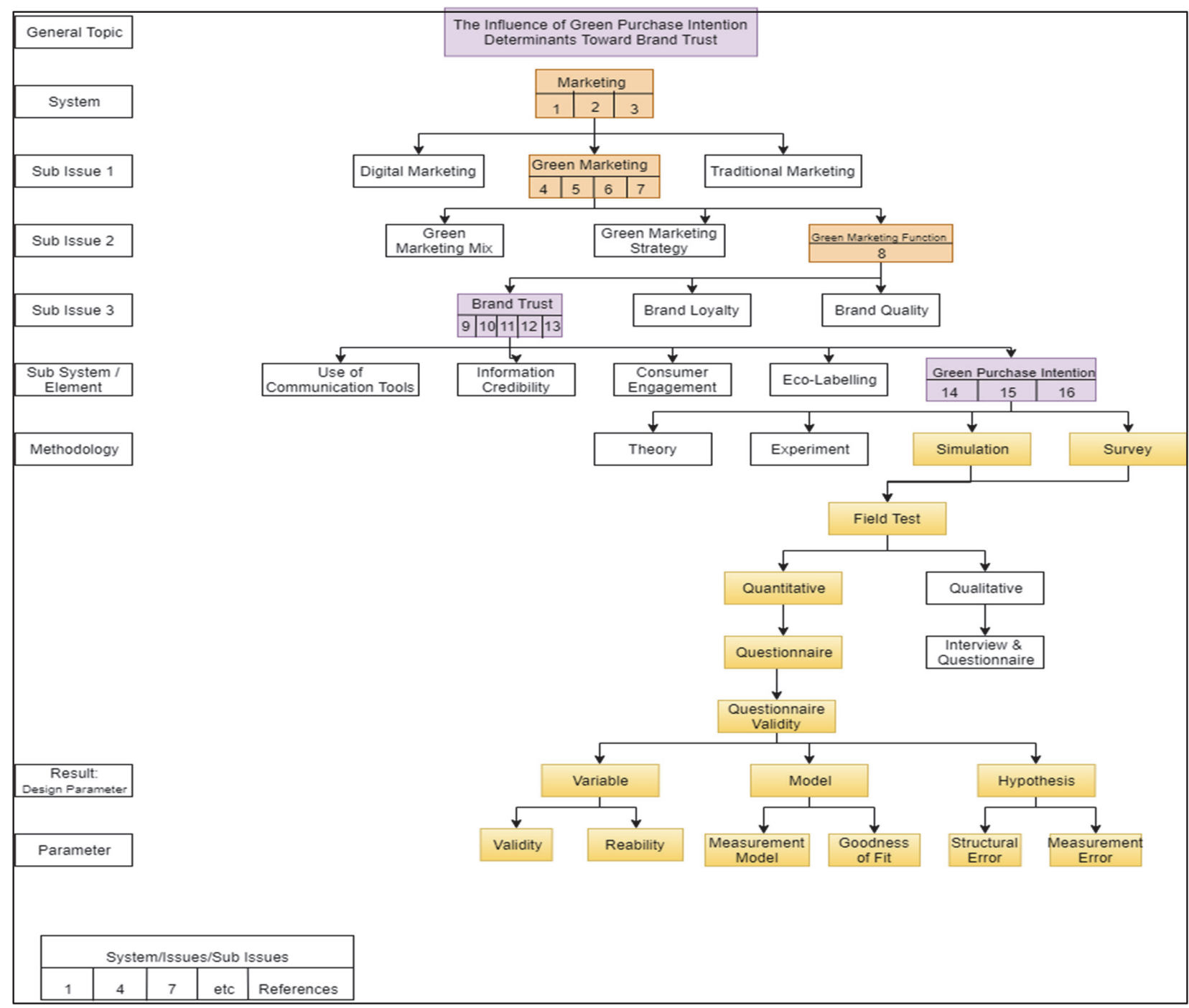

Table 1

Fig. 1. CK-Chart of research

CK-Chart Resources

\begin{tabular}{|c|c|c|}
\hline $\begin{array}{c}\text { Number of } \\
\text { Journal }\end{array}$ & Sub Issue and Sub System & Source(s) \\
\hline $1,2,3$ & Marketing & $\begin{array}{l}\text { (Fernandes \& Solimun, The mediation effect of customer satisfaction in relationship between service } \\
\text { quality, service orientation and marketing mix strategy to customer loyalty, 2018), (Kotler \& Keller, } \\
\text { 2012), (Kumar R. V., 2013) }\end{array}$ \\
\hline $4,5,6,7$ & Green Marketing & $\begin{array}{l}\text { (Kushwaha \& Kumar, 2014), (Chen, Chang, Yeh, \& Cheng, 2014), (Zhang, Li, Cao, \& Huang, } \\
\text { 2018), (Sitkin, 2011) }\end{array}$ \\
\hline 8 & Green Marketing Function & (Kumar P. , State of Green Marketing Research 25 years (1990-2014), 2016) \\
\hline $9,10,11,12,13$ & Brand Trust & $\begin{array}{l}\text { (Atkinson \& Rosenthal, 2014), (Zhao, Huang, \& Su, 2019), (Fung So, King, Sparks, \& Wang, 2014), } \\
\text { (Sadek, Redding, \& Tantawi, 2015), (Lee, Kim, \& Chan-Olmsted, 2011) }\end{array}$ \\
\hline $14,15,16$ & Green Purchase Intention & (Chekima B., Wafa, Wafa, Igau, \& Chekima, 2015), (Lee K. , 2008), (Chan, 2001) \\
\hline
\end{tabular}




\subsection{Marketing}

Marketing is one of the main activities that should be conducted by the company in order to survive in this era. Marketing have more contact with consumers than the other functions within a company. A company need to know how to market a product or service appropriately in order to make those product or service are meet customers' needs and provide satisfaction to the customers (Fernandes \& Solimun, 2018). Although the definition does not directly determine society or the environment, a reflection will make it clear that marketing cannot exist without society or the environment. This implicit belief in the importance of society and the environment leads to new developments in the field of marketing culminate in the concept of sustainable marketing and green marketing (Kumar, 2013).

\subsection{Green Marketing}

Green marketing or environmental marketing refers to ecological products such as healthy food, phosphate-free, recyclable, refillable ozone friendly and eco-friendly (Kushwaha \& Kumar, 2014). According to Polonsky (1994), green marketing is conformable with all activities that design services and facilities to satisfy consumer needs and wants without impacting on their environment. According to the American Marketing Association (AMA), green marketing is the development and marketing of products designed to reduce the negative physical impact on the environment or to improve its quality (American Marketing Association Editor). With increased serious environmental problem, green consumption has given more attention by companies and consumers. Consumers are enthusiast to purchase green product that are environmentally friendly in consequence of environmental considerations (Chen et al., 2014). The increasing demand for green consumption encourages firms to develop green marketing strategies to show consumers their good company image and social responsibility (Zhang et al., 2018).

\subsection{Green Marketing Function}

Green marketing functions addressed issues related to products, promotion, retailing and distribution, and other issues such as branding, positioning and international marketing. Green branding literature discussed building green brand trust, brand loyalty, brand quality, antecedents of green brand, and relationship between environmental orientation and brand value $(\mathrm{Ku}-$ mar, 2016).

\subsection{Brand Trust}

Brand Trust is the customers' willingness to rely on the brand in term of facing the risk which caused by the expectation that the brand will cause positive outcomes. The definition of brand trust proposed reflects two distinct components: (1) brand reliability, and (2) brand intentions. Brand reliability is essential for trusting a brand because the accomplishment of the value promise that the brand represents to the market leads the consumer to be confident about the occurrence of future satisfaction. Brand intentions are based on the consumer' belief that the brand would hold the consumer's interest when unexpected problems with the consumption of the product arise (Yague-Guillen et al., 2003). The variables of Brand Trust are: Eco-Label (Atkinson \& Rosenthal, 2014), Green Purchase Intention (Zhao et al, 2019), Customer Engagement (Fung So et al, 2014), Communication Tools (Sadek et al, 2015), Information Credibility (Lee et al, 2011). This research is focused on Green Purchase Intention. Here are the explanations of each variables:

1. Eco Label: One of the important elements of green product development is the promotion of eco-labels on the products. Eco labelling is an effective tool which can provide the information on two main functions which is the information function that addresses the quality characteristics of the tangible product and the value function which provides the corporate environmental image of the firm (Sammer \& Wustenhagen, 2006).

2. Green Purchase Intention: According to (Mutiara \& Satoshi, 2017) the intention to buy green product defined as an individual's readiness to perform green buying behaviour, specifically reflecting the consideration of less pollution. While determinants of green purchase intentions are determinants of customers in making green purchases.

3. Customer Engagement: Engagement is most often conceptualized as consumer engagement or consumer brand engagement has an objective to express the cognitive, emotional and behavioural connection a customer has with a firm or brand (Hollebeek, Glynn, \& Brodie, 2014). In recent expression of service system theory, engagement is employed as a synonym for activity or interaction which it is no longer a property of individual actor (Abdul-Ghani et al., 2018).

4. Communication Tools: Communication with the customer is an important factor in the success of green innovation. When implementing environmentally friendly products, companies use marketing tools that are well established and proven for other products (Zauskova et al., 2015). All of the marketing tools and strategies are inherent in advertising. They are very common as the fundamental principle of advertising is to provide a positive and praiseworthy product's reference (Rabova, 2015).

5. Information Credibility: Information credibility is defined as an important aspect of individual subjective evaluation of the information obtained. The credibility of information is investigated with questions that ask about the estimated accuracy of the information available (Zhu et al., 2011).

2.5 Green Purchase Intention: Consumer's purchase intention is well-known as a subjective and wide field in consumer behaviour and part of purchase decision making. People all over the world tend to testify the different response towards many determinants that believed to stimulate one's purchase intention (Chekima et al., 2015). Other than that, purchase intention refers to the tendency to buy a certain brand or product or how likely the individual would purchase a product 
(Belch \& Belch, 2015). The likelihood that a consumer will buy a particular product results from the interaction of his or her need for it, attitude towards it, perceptions of it and the company which produces it (Bradmore, 2004).

In accordance with the definitions above, Lee (2008) defined green purchasing as "the purchasing of procurement efforts which give preferences to products or services which are least harmful to the environmental and human health". While Chan (2001) defined green purchasing as a specific kind of eco-friendly behaviour that consumers perform to express their concern to environment. As for some determinant factors that support the purchase intention of a product, among them are:

1. Price: Price has been regarded as either monetary sacrifice for obtaining a product or quality signal of a product (Lichtenstein et al., 1993). While from the consumer's perspective, price represents the amount of money consumers must give up to get the product or service. Consumers do not always remember the actual price of products. Instead, they encode prices in way that are meaningful to them (Zeithaml, 1988). Instead of a single price, consumers usually have a range of prices that are acceptable for an intended purchase (Lien et al., 2015).

2. Eco Label: Eco-labels refer to a product's collective overall environmental performance. They are indicators of the environmental performance of a product, developed to try to prevent consumers from being confused over claims of environmental friendliness (Childs \& Whiting, 1998).

3. Environmental Attitude: Environmental Attitude is a person's attitude towards environmental concern. Environmental attitude is defined as a learned predisposition to respond consistently favourable or unfavourable manner with respect to the environment (Rashid, 2009). Attitude, as opposed to knowledge and behaviour, is the most significant predictor of consumers' willingness to pay more for ecologically favourable products (Laroche et al., 2001).

4. Environmental Advertising: Exposure to green advertising be incentivized to individuals who possess favourable environmental attitude and have cultural values by encouraging them to form stronger intention to buy green products (Chekima et al., 2015). The role of advertising in informing consumers, either directly or indirectly can develop consumers' feelings and judgements toward such advertisement claims, which affects their attitude towards the ad and beliefs about the brand and hence their intention to purchase (Batra \& Ray, 1986).

5. Long-term Orientation: Long-term orientation is among the dimensions of cultural orientation that deals with time-past, present and future (Chekima et al., 2015). Bearden et al. (2006) stated that long-term orientation influences ethical values level of a person that referred as the extent to which individuals considered accepted norms of right and wrong in their decisions. Thus, it would be expected that those who plan for future success would be less likely to engage in conventional purchasing behaviour because such behaviour if discovered holds very negative long-term consequences as this will have impact on environmental damage.

6. Brand Image: Brand image is a determinant affecting customers' subjective perceptions and consequent behaviours. Keller (1993) stated that brand image is a perception about a brand as reflected by the brand association held in consumers' memory. Brand image influence a consumer in recognizing their needs regarding the brand and distinguishes the brand from other rivals. The more favourable brand image, the more positive attitude toward the branded product and its attributes.

7. Bad Review: Few recent studies investigate the impact of online reviews on consumers' purchase decision. Bad review is a negative review given by the consumers related to high price and low rating. While satisfaction rather than dissatisfaction affects people more for writing reviews (Ogut \& Cezar, 2012).

Table 1

Source of Each Variables

\begin{tabular}{cc}
\hline Instruments & Source(s) \\
Price & (Lien et al, 2015) \\
Brand Image & \\
Environmental Attitude & \\
Environmental Advertising & Eco-Label \\
Long-term Orientation & (Chekima et al, 2015) \\
Bad Review & \\
Green Purchase Intention & (Ogut \& Cezar, 2012) \\
\hline
\end{tabular}

\section{Methodology and materials}

\subsection{Research objective}

The focus of this research is green marketing analysis and the effect of green purchase intention determinants at Real Estate Indonesia (REI) Yogyakarta. This location selection is based on the promotion that has been carried out by the company which invites consumers to be more concerned about the environment.

\subsection{Population and Sample}

According to Sugiyono (2013), the population is a generalization area consisting of objects or subjects that have certain qualities and characteristics set by researchers to be studied and then conclusions drawn. In this research, the population is 
700 peoples who are consumers of several brand developers of property who are bound in Real Estate Indonesia (REI) Yogyakarta. Sample is part of the number and characteristics possessed by the population. This study uses 400 sample from the population.

\subsection{Data Collecting Method}

In this study, the method used is a survey method with a questionnaire. The questionnaire to be used has a list of research related statements and is prepared with answer choices in the form of a Likert scale. Measurement of the Likert scale is by giving a statement to the respondent by giving the answer scale with a score of 1 to 5 .

\subsection{Data Processing Method}

In this study, the data generated will be analyzed using the SEM method with software used is AMOS version 22. There are seven steps in SEM include development of theoretical models, compiling path diagrams, compiling structural equations, selecting matrix inputs and estimation techniques, assessing model identification, evaluating goodness of fit criteria, and modifying model.

\subsection{Research Model}

The concept of this research model is about determinants of green purchase intentions. In this study several variables were used to determine the effect of its variables to green purchase intention. Then, from those variables obtained several hypotheses as follows:

Price represents the amount of money that must be given up, and therefore higher prices negatively affect purchase probabilities (Lichtenstein et al., 1993). Based on the research that conducted by Lien et al. (2015), price has a significant positive impact on purchase intention. Then from this explanation can be proposed the hypothesis that prices influence green purchase intention (H1). The next variables that consider as the important topic in marketing as a tool that affect green purchase intentions is eco-label. The eco-label on the products creates a distinct image to the consumers' cognition and the positioning of a product create the consumers' first choice of purchase (Purohit, 2012). Eco-labels are potentially interesting instruments that inform consumers about the environmental impact of their purchasing decisions (Yan \& Yazdanifard, 2014). From these definitions a hypothesis can be drawn that eco-label influence green purchase intention (H2). Environmental attitude is defined as a learned predisposition to respond consistently favourable or unfavourable manner with respect to the environment (Rashid, 2009). The attitude behaviour toward green product is significant related to purchasing behaviour (Goriparthi \& Tallapally, 2017). The more a person is morally obliged to protect the environment and save limited natural resources on earth, then a more positive attitude will be expressed in behaviour or action. One form of action to protect the environment is to buy green products. Based on the explanation above, the hypothesis can be proposed that environmental attitude influence green purchase intention (H3). One strategy to improve environmentally friendly behaviour is with information. Information can be delivered using advertisements (Chekima et al, 2015). Thus, it can be assumed that when someone has gotten information from an advertisement and is interested in buying because of that ad, then that person can finally be declared to have a higher intention in buying green products from advertisement. Consumers form cognition and conation when exposed to an advertisement which affects their attitude towards the ad and beliefs about the corporate image (Khandelwal \& Bajpai, 2011). Then it can be arranged the next hypothesis is environmental advertising influence green purchase intention (H4). Long-term orientation is a prominent facet of national culture values and of itself influences consumers' decision-making process (Bearden et al., 2006). Long-term oriented person will more likely to plan ahead before making purchase and are less tempted by immediate desires or quick outcome derive from their purchase. The person who have long-term orientation values will assess environmentally friendly behaviour/action such as engaging in green purchase intention is appropriate and reasonable to harmonize with environment (Chekima et al., 2015). From explanation above, the hypothesis can be proposed that long-term orientation influence green purchase intention (H5). Brand image is a determinant affecting customers' subjective perceptions and consequent behaviours. Keller (1993) stated that brand image is a perception about a brand as reflected by the brand association held in consumers' memory. Brand image influence a consumer in recognizing their needs regarding the brand and distinguishes the brand from other rivals. The more favourable brand image, the more positive attitude toward the branded product and its attributes. From this statement, it can be made a hypothesis that brand image influence green purchase intention (H6). Bad review is a negative review given by the consumers related to high price and low rating. While satisfaction rather than dissatisfaction affects people more for writing reviews (Ogut \& Cezar, 2012). From the previous journal, bad review could affect the purchase intention. Therefore, it could be used as a hypothesis that bad review influence green purchase intention (H7). From the proposed hypothesis described above, in Fig. 2 is a draft concept of the research model to be carried out.

\section{Results and findings}

The stages of testing carried out include three stages including:

\subsection{Validity and Reliability Test}




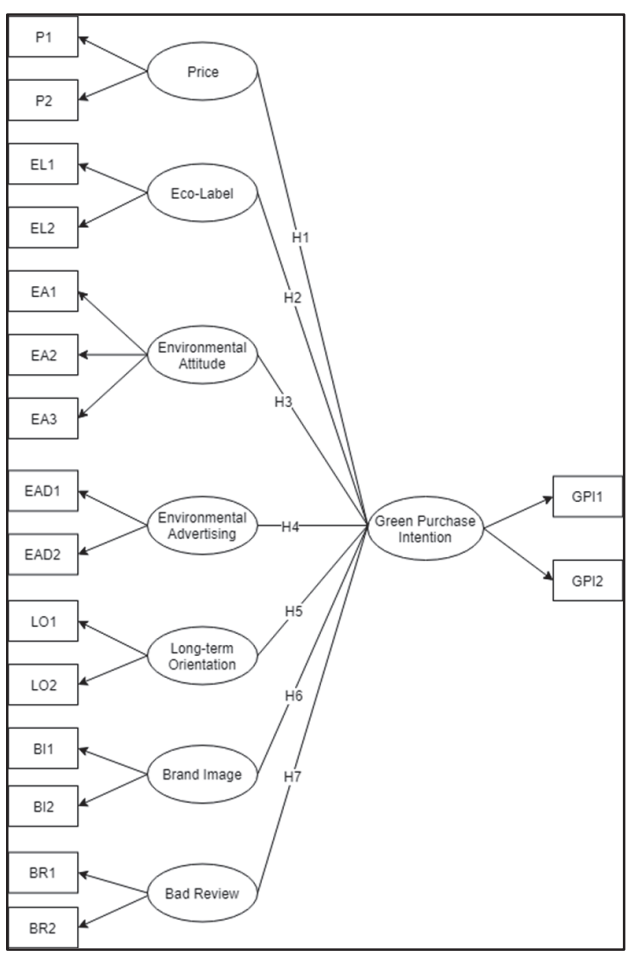

Fig. 2. Conceptual Model

Table 2

Validity and Reliability

\begin{tabular}{|c|c|c|c|c|c|c|}
\hline Variable & Indicator & Standard Loading & Standard Loading ${ }^{2}$ & Measurement Error & $\mathrm{CR}$ & $\mathrm{AVE}$ \\
\hline \multirow[t]{4}{*}{ Price } & $\mathrm{P} 1$ & 1,691 & 2,859481 & $-1,859481$ & \multirow{4}{*}{1} & \multirow{4}{*}{1} \\
\hline & $\mathrm{P} 2$ & 1 & 1 & 0 & & \\
\hline & $\sum$ & 2,691 & 3,859481 & $-1,859481$ & & \\
\hline & $\sum^{2}$ & 7,241481 & & & & \\
\hline \multirow[t]{4}{*}{ Eco-Label } & EL1 & 0,432 & 0,186624 & 0,813376 & \multirow{4}{*}{0,7} & \multirow{4}{*}{0,6} \\
\hline & EL2 & 1 & 1 & 0 & & \\
\hline & $\sum$ & 1,432 & 1,186624 & 0,813376 & & \\
\hline & $\sum^{2}$ & 2,050624 & & & & \\
\hline \multirow{5}{*}{$\begin{array}{l}\text { Environmental } \\
\text { Attitude }\end{array}$} & EA1 & 1,005 & 1,010025 & $-0,010025$ & \multirow{5}{*}{0,9} & \multirow{5}{*}{0,8} \\
\hline & EA2 & 1 & 1 & 0 & & \\
\hline & EA3 & 0,661 & 0,436921 & 0,563079 & & \\
\hline & $\sum$ & 2,666 & 2,446946 & 0,553054 & & \\
\hline & $\sum^{2}$ & 7,107556 & & & & \\
\hline \multirow[t]{4}{*}{ Environmental Advertising } & EAD1 & 3,78 & 14,2884 & $-13,2884$ & \multirow{4}{*}{1} & \multirow{4}{*}{1} \\
\hline & EAD2 & 1 & 1 & 0 & & \\
\hline & $\sum$ & 4,78 & 15,2884 & $-13,2884$ & & \\
\hline & $\sum^{2}$ & 22,8484 & & & & \\
\hline \multirow[t]{4}{*}{ Long-term Orientation } & LO1 & 0,961 & 0,923521 & 0,076479 & \multirow{4}{*}{0,9} & \multirow{4}{*}{0,9} \\
\hline & $\mathrm{LO} 2$ & 1 & 1 & 0 & & \\
\hline & $\sum$ & 1,961 & 1,923521 & 0,076479 & & \\
\hline & $\Sigma^{2}$ & 3,845521 & & & & \\
\hline \multirow[t]{4}{*}{ Brand Image } & BI1 & 0,501 & 0,251001 & 0,748999 & \multirow{4}{*}{0,7} & \multirow{4}{*}{0,6} \\
\hline & $\mathrm{BI} 2$ & 1 & 1 & 0 & & \\
\hline & $\sum$ & 1,501 & 1,251001 & 0,748999 & & \\
\hline & $\sum^{2}$ & 2,253001 & & & & \\
\hline \multirow[t]{4}{*}{ Brand Review } & BR1 & 0,581 & 0,337561 & 0,662439 & \multirow{4}{*}{0,7} & \multirow{4}{*}{0,6} \\
\hline & BR2 & 1 & 1 & 0 & & \\
\hline & $\sum$ & 1,581 & 1,337561 & 0,662439 & & \\
\hline & $\sum^{2}$ & 2,499561 & & & & \\
\hline \multirow[t]{4}{*}{ Green Purchase Intention } & GPI1 & 1 & 1 & 0 & \multirow{4}{*}{1} & \multirow{4}{*}{1} \\
\hline & GPI2 & 1,145 & 1,311025 & $-0,311025$ & & \\
\hline & $\sum$ & 2,145 & 2,311025 & $-0,311025$ & & \\
\hline & $\sum^{2}$ & 4,601025 & & & & \\
\hline
\end{tabular}

In the table above, it can be seen that the value of construct reliability of the eight variables is greater than the cut-off value of 0.7 , the indicators has good internal consistency. Then for extracted variance values it will be smaller than the value of 
construct reliability. Because the eight variables obtain values of more than 0.5 indicate that the number of variances of the indicators extracted by latent variables is more than the error variances.

\subsection{Structural Model Test}

\section{Structural Model}

The structural model is a relationship between latent variables (variables that cannot be measured directly and require supporting indicators to measure them) independent and dependent (Bollen, 1989). The results of the structural model test can be seen in Fig. 3.

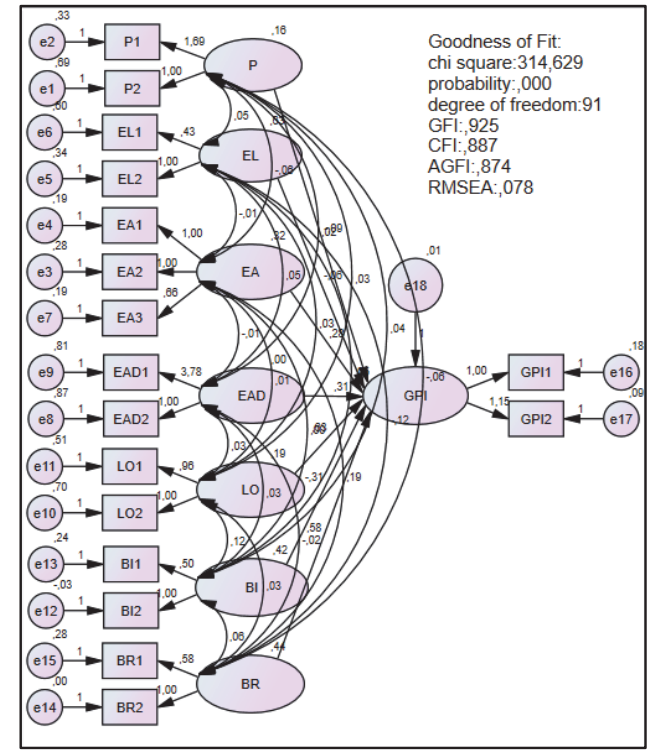

Table 3

Assessment of normality

\begin{tabular}{crrrrrr}
\hline Varia- & Min & max & skew & c.r. & kurto- & c.r. \\
\hline GPI2 & 3,000 & 5,000 &,- 214 & $-1,747$ & $-1,076$ & $-4,395$ \\
\hline GPI1 & 3,000 & 5,000 &,- 044 &,- 356 & $-1,036$ & $-4,228$ \\
BR1 & 3,000 & 5,000 &,- 026 &,- 209 &,- 672 & $-2,745$ \\
BR2 & 3,000 & 5,000 &,- 042 &,- 339 &,- 735 & $-3,002$ \\
BI1 & 2,000 & 5,000 &, 156 & 1,273 &, 164 &, 668 \\
\hline BI2 & 2,000 & 5,000 &, 034 &, 280 &,- 178 &,- 725 \\
LO1 & 2,000 & 5,000 &,- 357 & $-2,913$ &,- 439 & $-1,792$ \\
\hline LO2 & 2,000 & 5,000 &,- 368 & $-3,001$ &,- 747 & $-3,050$ \\
\hline EAD1 & 2,000 & 5,000 &,- 385 & $-3,145$ &,- 828 & $-3,382$ \\
EAD2 & 2,000 & 5,000 &,- 178 & $-1,453$ & $-1,099$ & $-4,485$ \\
EA3 & 3,000 & 5,000 &, 014 &, 113 &,- 185 &,- 756 \\
EL1 & 2,000 & 5,000 &,- 063 &,- 516 &,- 743 & $-3,035$ \\
EL2 & 2,000 & 5,000 &,- 120 &,- 980 & $-1,073$ & $-4,381$ \\
\hline EA1 & 3,000 & 5,000 &,- 033 &,- 273 & $-1,066$ & $-4,350$ \\
EA2 & 3,000 & 5,000 &,- 117 &,- 958 & $-1,334$ & $-5,444$ \\
P1 & 2,000 & 5,000 &,- 346 & $-2,825$ &,- 940 & $-3,837$ \\
P2 & 2,000 & 5,000 &,- 388 & $-3,171$ &,- 884 & $-3,608$ \\
Multi- & & & & & $-6,049$ & $-2,380$ \\
\hline & & & & & &
\end{tabular}

Fig. 3. Structural Model

\section{Data Normality Test}

Data normality test is done to see the level of normality of the data used in the study. This test is conducted by looking at the value of the critical ratio skewness of \pm 2.58 at the significance level of $0.001(1 \%)$. Data will be said to be normally distributed if the value of the critical ratio skewness value is below \pm 2.58 (Ghozali, 2005). Based on the calculation results, not all indicators have a critical ratio skewness value below \pm 2.58 . The data used in this study is data derived from primary data based on respondents' answers so that it is difficult to obtain data that follows a perfectly normal distribution.

\section{Outlier Evaluation}

Outlier evaluation is done to see univariate outliers and multivariate outliers. To see the multivariate outlier is done by looking at the malanhobis distance value. In this test the distance malanhobis value is compared with the chi-square value. If the malanhobis distance value is greater than the chi-square value, there is a multivariate outlier problem (Ferdinand, 2000). In this study the chi-square value obtained was 314.629 and the greatest value on the malanhobis distance was 40.79. Therefore, it can be concluded that in this study there were no multivariate outlier problems so that the data was feasible to use.

\section{Goodness of Fit Model}

The test results of the goodness-of-fit model are explained in Table 5.

Table 4

Result of goodness of fit model

\begin{tabular}{|c|c|c|c|c|}
\hline No & Index & Critical Value & Model Result & Category \\
\hline 1 & Probability & $\geq 0,05$ & 0 & Good \\
\hline 2 & $\mathrm{Cmin} / \mathrm{df}$ & Between 2-5 & 3,457 & Good \\
\hline 3 & Chi-Square & $\leq 114,26$ & 314,629 & Bad \\
\hline 4 & GFI & $\geq 0,90$ & 0,925 & Good Fit \\
\hline 5 & RMSEA & $<0,1$ & 0,078 & Good Fit \\
\hline 6 & RMR & $\leq 0,05$ & 0,03 & Good Fit \\
\hline 7 & AGFI & $\geq 0,90$ & 0,874 & Marginal \\
\hline 8 & IFI & $\geq 0,90$ & 0,889 & Marginal \\
\hline 9 & CFI & Between $0-1$ and close to 1 indicates very well & 0,887 & Marginal \\
\hline 10 & NFI & $\geq 0,90$ & 0,851 & Marginal \\
\hline
\end{tabular}


These results indicate that the model used is acceptable. The CMIN / DF value is obtained by dividing the chi square value and df which is 314.629 divided by 91 , then the result is of 3.457 shows a good structural equation model. Chi-square value obtained from CHIINV of df 91 and probability 0.05 which is 114.26 The RMSEA measurement index is in the range of expected values, namely $\leq 0.5$ is close fit and $\leq 0.08$ is good, which is 0.078 . Although chi-square is not good and AGFI, IFI, CFI, and also NFI are marginal which is close to the critical value. from several model feasibility tests, the model is said to be feasible if at least one of the feasibility test models is met (Hair et al., 2006).

\section{Model Interpretation}

The final stage in SEM is the interpretation of the model and modification of the model that does not meet the testing requirements. After the model is estimated, the residue must be small and close to zero and the distribution frequency of the residual covariance must be symmetrical. If the residual value is greater than $5 \%$ of all covariance variables produced by the model, modifications need to be considered on a theoretical basis. The cut off value with a range of -2.58 to 2.58 can be used to assess the residual significance produced by the model. Standardized residual covariances data can be seen in Table 6 .

Table 5

Standardized Residual Covariances

\begin{tabular}{|c|c|c|c|c|c|c|c|c|c|c|c|c|c|c|c|c|c|}
\hline & GPI12 & GPI12 & BR1 & BR2 & BI1 & BI2 & LO1 & LO2 & EAD1 & EAD2 & EA3 & EL1 & EL2 & EA1 & EA2 & P1 & P2 \\
\hline GPI12 & 0,524 & & & & & & & & & & & & & & & & \\
\hline GPI11 & 0,378 & 0,509 & & & & & & & & & & & & & & & \\
\hline BR1 & 0,209 & 0,182 & 0,429 & & & & & & & & & & & & & & \\
\hline BR2 & 0,359 & 0,314 & 0,254 & 0,441 & & & & & & & & & & & & & \\
\hline BI1 & $-0,1$ & $-0,009$ & 0,017 & 0,029 & 0,349 & & & & & & & & & & & & \\
\hline BI2 & $-0,21$ & $-0,18$ & 0,034 & 0,059 & 0,212 & 0,389 & & & & & & & & & & & \\
\hline LO1 & 0,121 & 0,105 & 0,018 & 0,031 & 0,058 & 0,117 & 0,692 & & & & & & & & & & \\
\hline $\mathrm{LO} 2$ & 0,126 & 0,11 & 0,018 & 0,032 & 0,061 & 0,122 & 0,187 & 0,891 & & & & & & & & & \\
\hline EAD1 & $-0,55$ & $-0,048$ & $-0,053$ & $-0,09$ & 0,057 & 0,114 & 0,1 & 0,105 & 0,865 & & & & & & & & \\
\hline EAD2 & $-0,15$ & $-0,013$ & $-0,014$ & $-0,02$ & 0,015 & 0,03 & 0,027 & 0,028 & 0,013 & 0,87 & & & & & & & \\
\hline EA3 & 0,159 & 0,139 & 0,072 & 0,124 & -0 & -0 & 0,005 & 0,006 & $-0,024$ & $-0,006$ & 0,331 & & & & & & \\
\hline EL1 & $-0,49$ & $-0,043$ & $-0,03$ & $-0,05$ & 0,01 & 0,02 & 0,012 & 0,013 & 0,085 & 0,023 & $-0,004$ & 0,719 & & & & & \\
\hline EL2 & $-0,113$ & $-0,099$ & $-0,071$ & $-0,12$ & 0,023 & 0,047 & 0,028 & 0,029 & 0,197 & 0,052 & $-0,009$ & 0,274 & 0,975 & & & & \\
\hline EA1 & 0,241 & 0,211 & 0,11 & 0,189 & -0 & -0 & 0,008 & 0,008 & $-0,037$ & $-0,01$ & 0,212 & $-0,01$ & $-0,013$ & 0,517 & & & \\
\hline EA2 & 0,24 & 0,21 & 0,109 & 0,188 & -0 & -0 & 0,008 & 0,008 & $-0,036$ & $-0,01$ & 0,211 & $-0,01$ & $-0,013$ & 0,321 & 0,603 & & \\
\hline $\mathrm{P} 1$ & $-0,103$ & $-0,09$ & $-0,055$ & $-0,1$ & 0,037 & 0,074 & 0,056 & 0,058 & 0,127 & 0,034 & $-0,071$ & 0,038 & 0,087 & $-0,11$ & $-0,108$ & 0,772 & \\
\hline P2 & $-0,61$ & $-0,053$ & $-0,033$ & $-0,06$ & 0,022 & 0,044 & 0,033 & 0,034 & 0,075 & 0,02 & $-0,042$ & 0,022 & 0,052 & $-0,06$ & $-0,064$ & 0,263 & 0,846 \\
\hline
\end{tabular}

Based on the table above the table shows that there is no standard covariance residual matrix that has a value outside the ring $-2.58 \leq$ standard residual $\leq 2.58$, so the model that is estimated does not need to be modified. And the model has been accepted through the feasibility test of the goodness of fit, modification of the model will not be carried out. Then, it will be continued in the next analysis.

\section{Hypothesis Testing}

Based on the results of the regression weight analysis above, it is showed that environmental attitude, long-term orientation, brand image and bad review have a significant effect on green purchase intention because their critical ratio is more than absolute 1.96 and the probability less than 0.05 . Whereas price, eco label, and environmental advertising have no significant effect on green purchase intention. Then based in this result, the researcher develops new model for the recommendation.

Table 6

Estimation Result

\begin{tabular}{lllrrrrl}
\hline & & & Estimate & S.E. & C.R. & P & Label \\
\hline GPI & $\leftarrow$ & P &,- 088 &, 111 &,- 792 &, 428 & par_10 \\
GPI & $\leftarrow$ & EL &,- 063 &, 076 &,- 831 &, 406 & par_11 \\
GPI & $\leftarrow$ & EA &, 285 &, 073 & 3,896 & $* * *$ & par_12 \\
GPI & $\leftarrow$ & EAD &, 306 & 1,065 &, 287 &, 774 & par_13 \\
GPI & $\leftarrow$ & LO &, 630 &, 177 & 3,557 & $* * *$ & par_14 \\
GPI & $\leftarrow$ & BI &,- 307 &, 089 & $-3,464$ & $* * *$ & par_15 \\
GPI & $\leftarrow$ & BR &, 579 &, 081 & 7,112 & $* * *$ & par_16 \\
\hline
\end{tabular}

\section{Model Recommendation}

Fig. 4 presents the summary of the proposed model. 


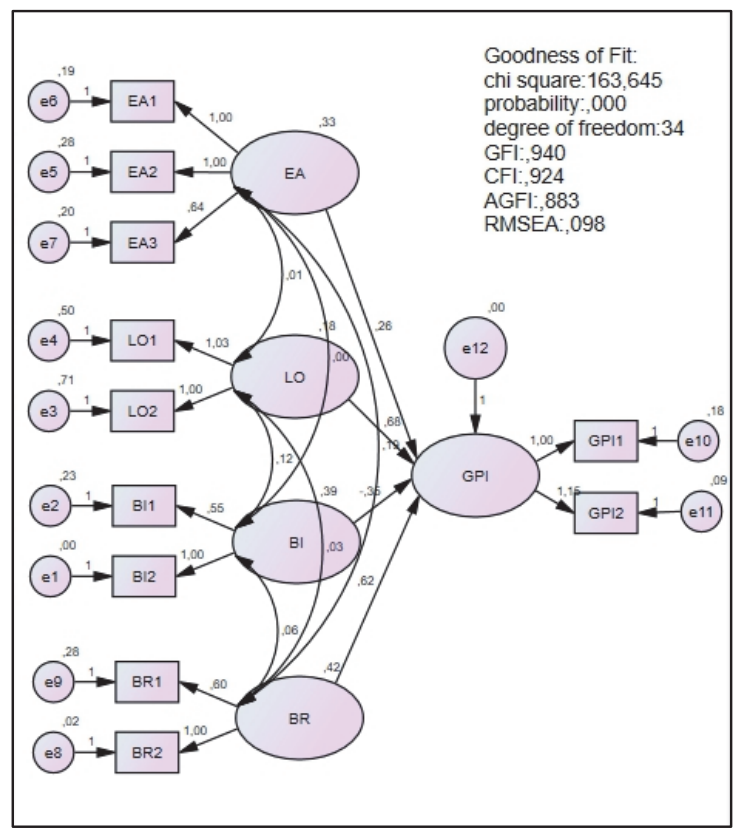

Fig. 1. Model Recommendation

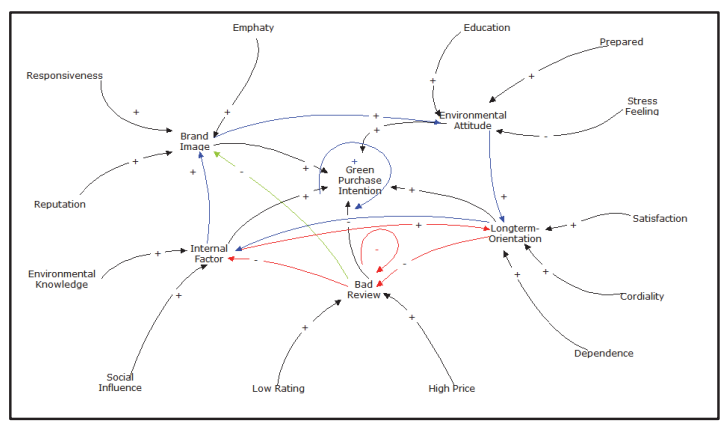

Fig. 2. Causal Loop Diagram for simulation

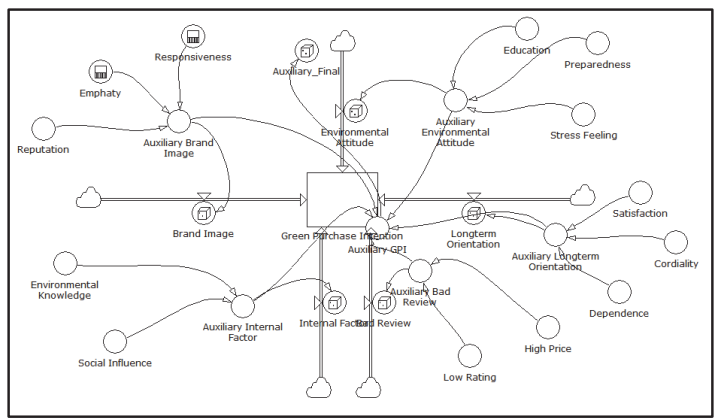

Flow diagram for simulation

\subsection{Hypothesis of Model Recommendation}

From the hypothesis testing result, there is some variables that are have no significant effect on green purchase intention. Then the model recommendation is given by AMOS. The model recommendation contains only the variables that have significant to green purchase intention. The estimation results for each exogenous variable with endogenous variables will be presented in Table 8 below.

Table 7

Regression Weights

\begin{tabular}{lllrrrrr}
\hline & & & Estimate & S.E. & C.R. & P & Label \\
\hline GPI & $\leftarrow$ & EA &, 258 &, 069 & 3,759 & $* * *$ & par_7 \\
GPI & $\leftarrow$ & LO &, 685 &, 170 & 4,023 & $* * *$ & par_8 \\
GPI & $\leftarrow$ & BI &,- 347 &, 084 & $-4,140$ & $* * *$ & par_9 \\
GPI & $\leftarrow$ & BR &, 622 &, 066 & 9,422 & $* * *$ & par_10 \\
\hline
\end{tabular}

Data analysis in the hypothesis can be seen from the regression weight value based on the value of the critical ratio of more than absolute 1.96 and the value of the probability is less than 0.05 . If it meets these conditions it can be said that the hypothesis is accepted or has a significant effect. From the regression analysis result above, it can be concluded that all the variables of recommendation are have significant to green purchase intention.

\subsection{Simulation}

\section{Causal Loop Diagram}

Based on the output results from the parameters, there is a recommendation of new model. The new variables use in new models are environmental attitude, environmental advertising, brand image, bad review. The output shows that all of the 4 variables are used to develop causal loop diagram (CLD) plus the internal green variable purchase intention factors. The causal loop diagram was built in the beginning to know the relationship among all of the variables and the indicator based on the main topic. There are positive relation and negative relation which can be seen in Fig. 5 . There are 2 loops which is positive loops and negative loops. Since the requirement of a proper CLD is to have minimum one loop interaction, the CLD of this research has already met the requirement. Thus, the CLD of this research is categorized as proper. 
Input Data

\begin{tabular}{llccccc}
\hline No & Variables & R1 & R2 & R3 & Geomean & round up/down \\
\hline 1 & Environmental Attitude & 3 & 3 & 1 & 2,080084 & 2 \\
2 & Education & 3 & 1 & 2 & 1,817121 & 2 \\
3 & Prepared & 2 & 2 & 3 & 2,289428 & 2 \\
4 & Stress Feeling & 2 & 1 & 3 & 1,817121 & 2 \\
\hline 5 & Long-term Orientation & 1 & 3 & 2 & 1,817121 & 2 \\
6 & Satisfaction & 2 & 1 & 2 & 1,587401 & 2 \\
7 & Cordiality & 3 & 2 & 1 & 1,817121 & 2 \\
8 & Dependence & 3 & 2 & 2 & 2,289428 & 2 \\
\hline 9 & Brand Image & 1 & 3 & 3 & 2,080084 & 2 \\
10 & Empathy & 2 & 2 & 1 & 1,587401 & 2 \\
11 & Responsiveness & 2 & 3 & 3 & 2,620741 & 3 \\
12 & Reputation & 3 & 1 & 2 & 1,817121 & 2 \\
\hline 13 & Internal Factors & 2 & 1 & 3 & 1,817121 & 2 \\
14 & Social Influence & 1 & 3 & 3 & 2,080084 & 2 \\
15 & Environmental Knowledge & 2 & 2 & 3 & 2,289428 & 2 \\
\hline 16 & Bad Review & 2 & 2 & 3 & 2,289428 & 2 \\
17 & High Price & 2 & 2 & 3 & 2,289428 & 2 \\
18 & Low Rating & 2 & 1 & 1 & 1,259921 & 1 \\
\hline
\end{tabular}

Simulation results are obtained from models that run over a period of 10 years and are seen per month. The following are the simulation results that have been obtained.

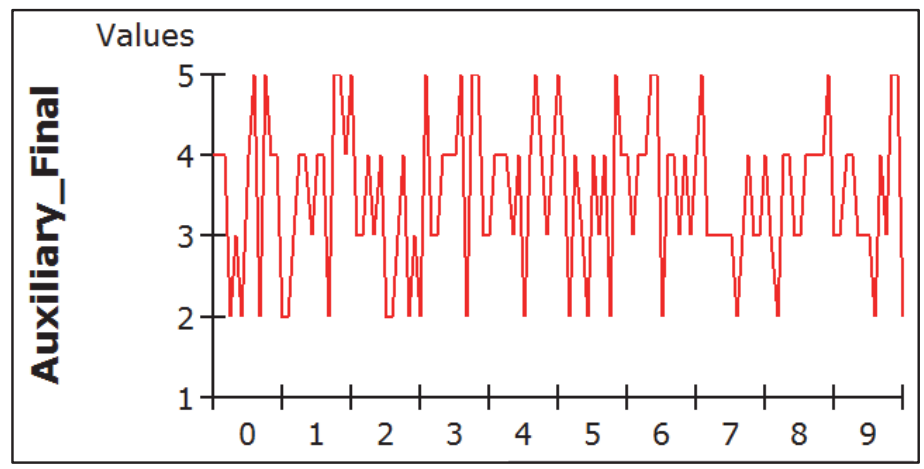

The following shows the simulation results year 2021 to 2029 .

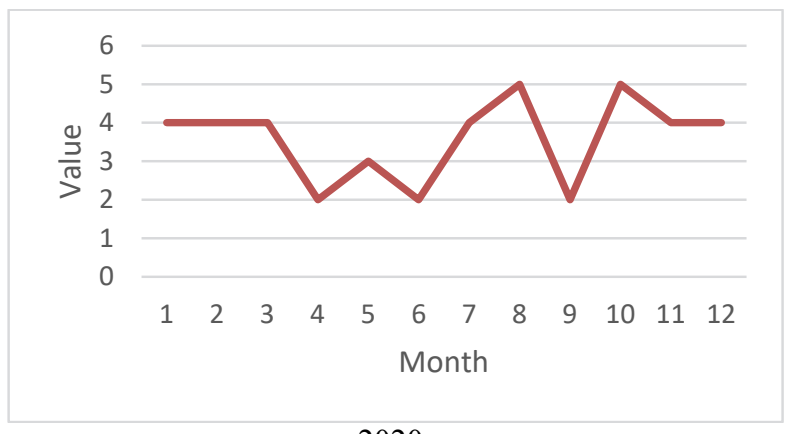

2020

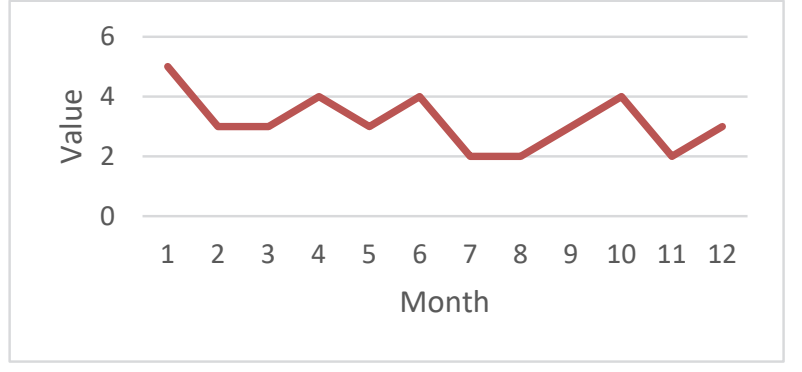

2022

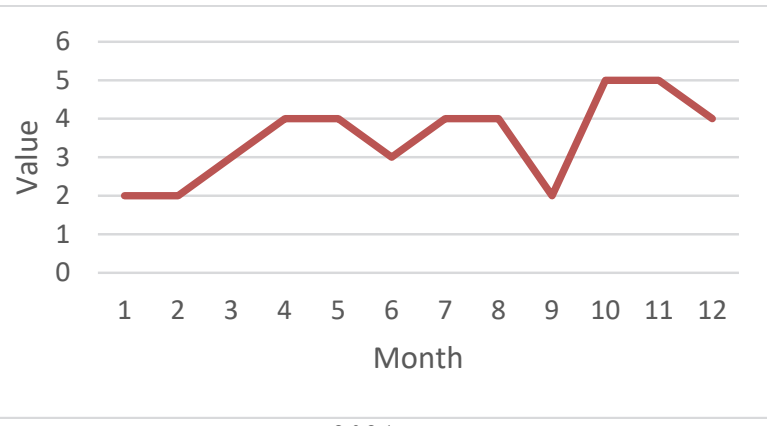

2021

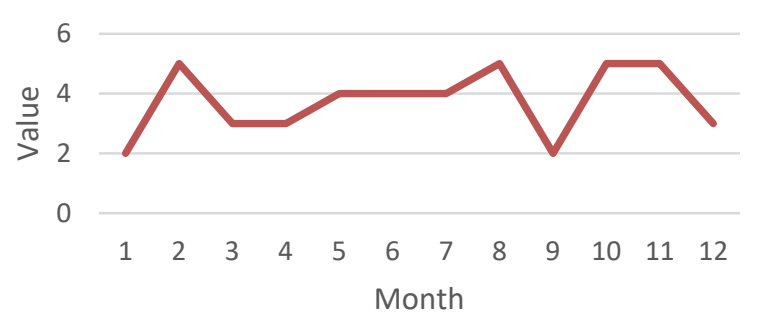

2023 


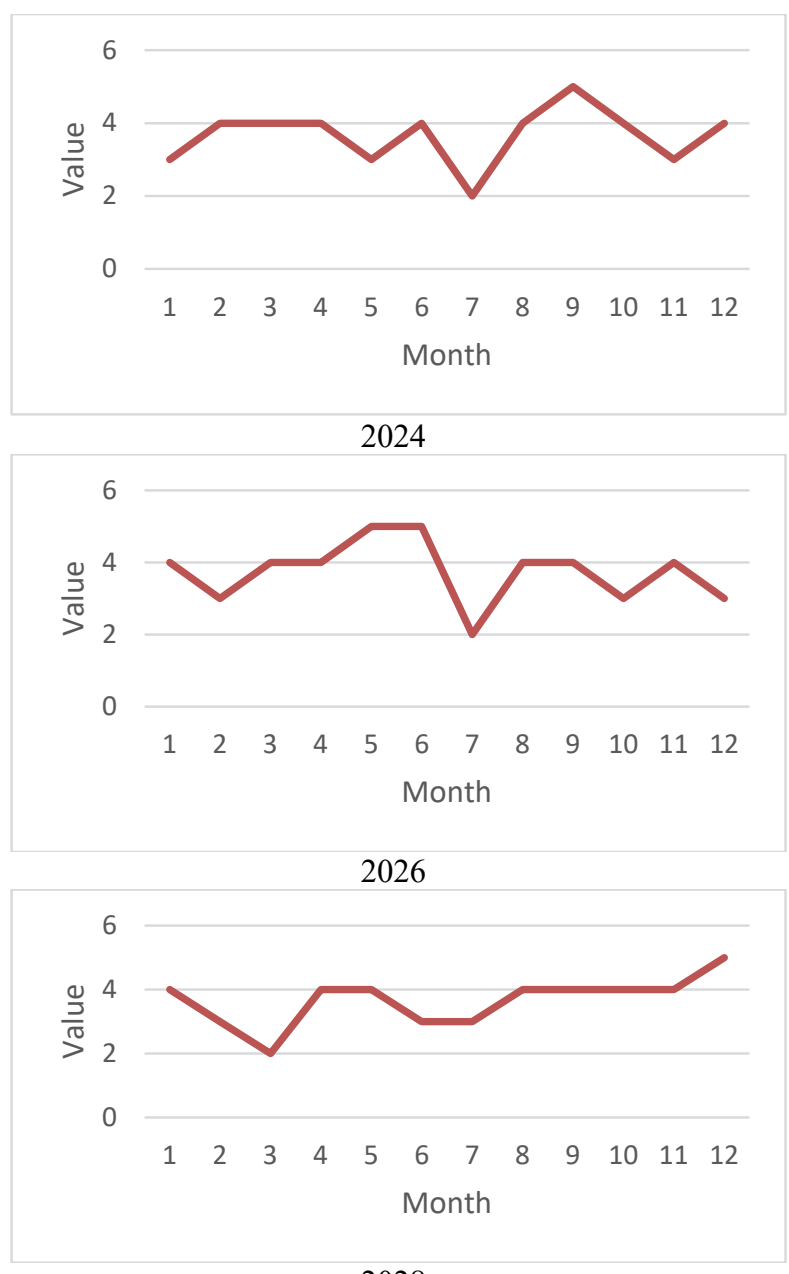

2028
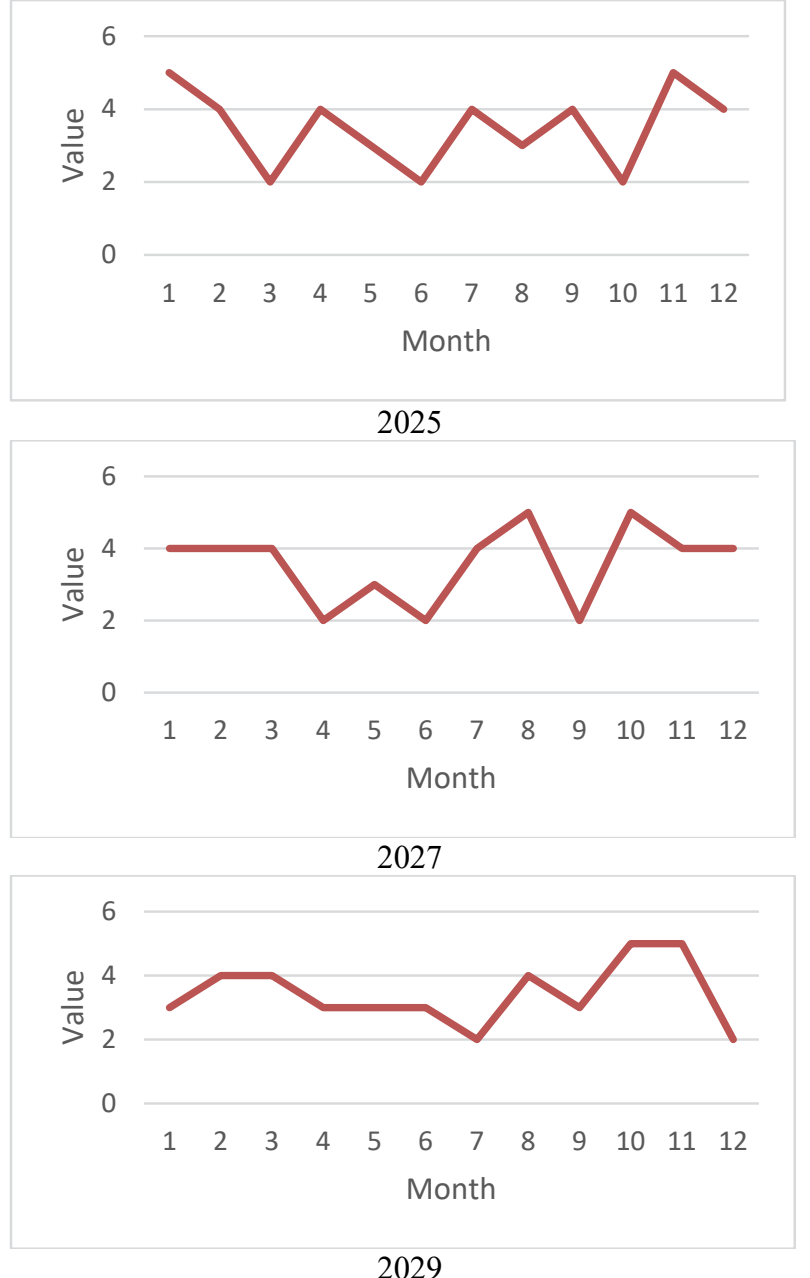

From the results presented in the figures for years 2020 to 2029, we understand that in year 2020 the best condition of green purchase intention at REI Yogyakarta is at month 8 and 10 which is in August and October while the results show that in year 2021 the best condition of green purchase intention at REI Yogyakarta was at month 10 and 11 which is in October and November. The simulation graph above also shows that in year 2022 the best condition of green purchase intention at REI Yogyakarta was at the first month which is January. Moreover, the figure shows that in year 2023 the best condition of green purchase intention at REI Yogyakarta was at month 5, 8, 10, and 11 which were in May, August, October, and November. In addition, From the simulation graph above, it can be seen that in year 2024 the best condition of green purchase intention at REI Yogyakarta is at month 9 which is in September. Other results are also seen on other figures.

\subsection{Findings}

This study using a survey method with an online questionnaire in the form of a google form. Based on the literature review, the data needed in testing the questionnaire is at least 300 respondents. The results of distributing questionnaires to 400 respondents, then carried out a model measurement test, test the structural model, and test the hypothesis.

(1) The validity and reliability test are carried out to determine the construct reliability (CR) and AVE value of a model. The table shows that the value of construct reliability of the eight variables is greater than the cut-off value of 0.7 , the indicators has good internal consistency. Then for extracted variance values it will be smaller than the value of construct reliability. Because the eight variables obtain values of more than 0.5 indicate that the number of variances of the indicators extracted by latent variables is more than the error variances.

(2) Testing of structural models includes data normality test, outlier evaluation, and goodness of fit test. In the data normality test, the calculation results show that not all indicators have a critical ratio skewness value below \pm 2.58 . Furthermore, the outlier evaluation compared the malanhobis distance values with the chi-square value. in this study the chi-square value obtained was 314.629 and the greatest value on the malanhobis distance was 40.769 . Therefore, it can be concluded that in this study there were no multivariate outlier problems so that the data was feasible to use. The goodness of fit test shows that the model used is acceptable. The CMIN / DF value of 3.457 shows a good structural equation model. The RMSEA measurement index is in the range of expected values, namely $\leq 0.5$ is close fit and $\leq 0.08$ good fit is 0.078 . the probability level is $0 \leq 0.05$ 
means that the probability is good. Although chi-square, AGFI, TLI are not good. The final stage in testing structural models is hypothesis testing.

(3) Hypothesis testing shows that 4 of the 7 variables used in this study have an influence on green purchase intention (probability <0.05). These variables are environmental attitude, long-term orientation, brand image and bad review. Thus H3, H5, H6 and $\mathrm{H} 7$ have a significant influence on green purchase intention. While the price, eco-label and environmental advertising variables have a probability value $>0.05$. Thus $\mathrm{H} 1, \mathrm{H} 2$ and $\mathrm{H} 4$ have no influence on green purchase intention.

From each year green purchase intention value simulation, there are several patterns that were found by the researcher while doing the result data analysis. In the simulation, the value of each indicator and variable were given by conducting expert judgement method with 3 experts. Before the data inputted, geomean result was calculated in Microsoft excel. In transferring the data to the model in Powersim. The results of the simulation based on the previous chapter show that there is an increase and decrease in green purchase intentions every year within a period of 10 years in every month. The months that most often have the highest values in simulations of this study are sequentially October, November and August. However, there is also moderate chance of eco-label value to drop in the seventh month of each year (July). The result obtained from the simulation could be used by Real Estate Indonesia (REI) or other companies that applied green purchase intention aspect within their organizations to support in decision-making process. The hypotheses that have no significant effect on green purchase intention does not mean that the research done failed. The existence of these indicators in this study is the cause of the insignificance of the hypothesis. Therefore, further research is needed to improve this research.

\section{Conclusion}

Based on the results of the study, it can be concluded (1) conceptual models that are built based on the literature review that has been done are declared valid. (2) variables that have a significant relationship or influence on green purchase intention are environmental attitude, long-term orientation, brand image and bad review. While variables that have no influence on green purchase intention are price, eco-label and environmental advertising. The focus on further research is on hypotheses on variables that do not have a significant relationship or do not affect the green purchase intention.

\section{References}

Atkinson, L., \& Rosenthal, S. (2014). Signaling the green sell: The influence of eco-label source, Argument specificity, and Product involvement on consumer trust. Journal of Advertising, 43(1), 33-45.

Batra, R., \& Ray, M. L. (1986). Affective responses mediating acceptance of advertising. Journal of Consumer Research, 13(2), 234-249.

Belch, G. E., \& Belch, M. A. (2015). Advertising and promotion : an integrated marketing communications perspective. 10e. New York: McGraw-Hill.

Bollen, K. A. (1989). Structural equations with latent variables. New York: John Wiley \& Sons.

Bradmore, D. (2004). Student attitudes to careers in sales: A Malaysian perspective. Malaysian Management Review, 39(2), 51-58.

Chan, R. Y. (2001). Determinants of chinese consumers' green purchase behavior. Psychology \& Marketing, 18(4), $389-413$.

Chekima, B., Wafa, S. A., Igau, O. A., \& Chekima, S. (2015). Determinant factors of consumers' green purchase intention: The moderating role of environment advertising. Asian Social Science, 11(10), 318-329.

Chen, Y.-S., Chang, C.-H., Yeh, S.-L., \& Cheng, H.-I. (2014). Green shared vision and green creativity: the mediation roles of green mindfulness and green self-efficacy. Qual Quant, 49(3), 1169-1184.

Childs, C., \& Whiting, S. (1998). Eco-labelling and the green consumers. West Yorkshire: Sustainable Business Publication.

Ferdinand, A. (2000). Structural equation modelling dalam penelitian manajemen. Semarang: Penerbit Universitas Diponegoro.

Fernandes, A. R., \& Solimun, S. (2018). The mediation effect of customer satisfaction in relationship between service quality, service orientation and marketing mix strategy to customer loyalty. Journal of Management Development, 37(1), 76-87.

Fung So, K. K., King, C., Sparks, B. A., \& Wang, Y. (2014). The Role of Customer engagement in building consumer loyalty to tourism brands. Journal of Travel Research, 1-15.

Ghozali, I. (2005). Aplikasi analisis multivariate dengan program SPSS. Semarang: Badan Penerbit Universitas Diponegoro.

Goriparthi, R. K., \& Tallapally, M. (2017). Consumers' attitude in green purchasing. FIIB Business review. 34-44. doi:10.29368/FIIB.6.1.2017.

Hair Jr, J. F., Black, W. C., Babin, B. J., \& Anderson, R. E. (2006). Multivariate data analysis 6th Ed. New Jersey: Pearson education.

Hollebeek, L. D., Glynn, M. S., \& Brodie, R. J. (2014). Consumer brand engagement in social media: conceptualization, scale development and validation. Journal of Interactive Marketing, 28(2), 149-165.

Khandelwal, U., \& Bajpai, N. (2011). A study on green advertisement and its impact on consumer purchase intention. Journal of Creative Communications, 6(3), 259-276.

Kotler, P., \& Keller, K. L. (2012). Marketing management 14e. New Jersey: Pearson education inc. 
Kumar, P. (2016). State of green marketing research over 25 years (1994-2014) : Literature survey and classification. Marketing Intelligence \& Planning, 34(1), 137-158.

Kushwaha, G. S., \& Kumar, A. (2014). Impact of green marketing practices on customer satisfaction among the leather industries' customers. Asia-pacific Journal of Management, 10(1), 79-88.

Lee, C., Kim, J., \& Chan-Olmsted, S. M. (2011). Branded product information search on the Web: The role of brand trust and credibility of online information sources. Journal of Marketing Communications, 17(5), 355-374.

Lee, K. (2008). Opportunities for green marketing: young consumers. Marketing Intelligence \& Planning, 26(6), 573-586.

Lee, Y. K. (2017). A comparative study of green purchase intention between korean and chinese consumers: The moderating role of collectivism. Sustainability, 9(10), 1-17.

Mutiara, V. I., \& Satoshi, A. (2017). The challenges in organic agricultural products market in southeast asia. Agricultural Science, 5, 36-44.

Ogut, H., \& Cezar, A. (2012). The factors affecting writing reviews in hotel websites. Social and behavioral sciences, 58, 980-986.

Polonsky, M. J. (1994). An introduction to green marketing. Electric Green Journal, 1(2).

Purohit, H. C. (2012). Product positioning and consumer attitude towards eco-friendly labeling and advertisement. Journal of Management Research, 12(3), 153-162. Retrieved from http:/www.i-scholar.in/index.php/jmr/article/view/37232

Rabova, T. K. (2015). Marketing communication of SMEs specialized in cosmetic industry in magazines for women. Procedia - Social and Behavioral Sciences, 175, 48-57.

Rashid, N. N. (2009). Awareness of eco-label in Malaysia's green marketing initiative. International Journal of Business and Management, 4(8), 132-141.

Sadek, H., Redding, P., \& Tantawi, P. (2015). Investigating the major marketing communication tools and their impact on building bank brand equity in the Egyptian context a customer perspective. Journal of Business and Retail Management Research, 10(1), 40-59.

Sammer, K., \& Wustenhagen, R. (2006). The Influence of eco-labelling on consumer behaviour - Results of a discrete choice analysis for washing machines. Business Strategy and the Environment, 15, 185-199.

Sitkin, A. (2011). Principles of ecology and management: International challenges for future practitioners. London: Goodfellow publishers.

Yan, Y. K., \& Yazdanifard, R. (2014). The concept of green marketing and green product development on consumer buying approach. Global Journal of Commerce \& Management Perspective, 3(2), 33-38.

Zeithaml, V. A. (1988). Consumer perceptions of price quality and value a means-end model and synthesis of evidence. Journal of Marketing, 52, 2-22.

Zhang, L., Li, D., Cao, C., \& Huang, S. (2018). The influence of greenwashing perception on green purchasing intentions: The mediating role of green word-of-mouth and moderating role of green concern. Journal of Cleaner Production, 187, 740-750.

Zhao, J.-D., Huang, J.-S., \& Su, S. (2019). The effects of trust on consumers' continuous purchase intentions in C2C social commerce: A trust transfer perspective. Journal of Retailing and Consumer Services, 50(C), 42-49. 
(C) 2021 by the authors; licensee Growing Science, Canada. This is an open access article distributed under the terms and conditions of the Creative Commons Attribution (CC-BY) license (http://creativecommons.org/licenses/by/4.0/). 